\title{
Protests, "acting-out", group psychology, surplus enjoyment and neoliberal capitalism
}

\section{Abstract}

How should one make sense of the recent student protests across South Africa, which seem to be motivated by grievances relating to various forms of financial exclusion, from registrationandtuitionfeestocosts ofaccommodation, and later pre-election protests, triggered by competition among would-be party candidates? It appears that Freud and Lacan's countervailing psychoanalytical concepts of "acting-out" and "transference" cast explanatory light on this variegated phenomenon - the former insofar as it is an index of repressed, unarticulated motives manifesting themselves in irrational behaviour resistant to "analysis", instead of ethically accountable "acts", and the latter, on the contrary, designating a process according to which subjects are receptive to, and act (or speak) according to the requirements of "successful analysis", including the "subject supposed to know". Cognisance must also be taken of the fact that the protestors constitute(d) groups, and that it should therefore be approached as such in psychoanalytical terms. Recourse to the Freudian notion of "group psychology" is heuristically helpful in this regard. This is augmented by focusing on what has, it is argued, functioned to trigger the protest behaviour, namely neoliberal capital, by way of considering Lacan's account of capitalist discourse in Seminar 17 - together with its insightful interpretation by Juliet MacCannell - particularly the relation between surplus value and surplus enjoyment.

Making sense of the recent, and still sporadically continuing university student protests (Allison, 2015; Chabalala, 2016; Hall, 2016; Msimang, 2016) across South Africa (and to a lesser extent the more recent pre-election protests concerning party candidate-lists), calls for a

\section{Bert Olivier}

Department of Philosophy

University of the Free State

Bloemfontein

OlivierG1@ufs.ac.za

\section{Keywords}

acting-out, capitalism, discourse, group psychology, jouissance, protests, transference 
fundamental theoretical approach. Although one could always address them at the level of "common sense" or everyday discourse, it is perhaps time to elaborate on the fruits yielded by a Freudian and Lacanian psychoanalytical perspective on the matter. Several other theoretical approaches are possible, for example that of Julia Kristeva, framed in terms of her recuperative concept of "revolt". Then there are the critical-theoretical principles underlying Theodor Adorno and Herbert Marcuse's responses to the student rebellion of the late 1960s in the context of the crisis of capitalism at the time, but in my view the most productive heuristic and theoretical angle on these events is found in the psychoanalytic theory referred to.

What are we dealing with when confronting the disconcerting spectacle of sometimes violent student protests in South Africa today, together with the unpredictable events they give rise to, such as the occurrence of violent attacks on protestors who had invaded a rugby field at the University of the Free State during a match between University of the Free State and Nelson Mandela Metropolitan University teams (Whittles, 2016)? One could easily dismiss these protests as the irrational actions of "spoilt" students, who (according to many observers) should return to their studies instead of wasting precious time and resources on redundant, childish remonstrations. In other words, as far as one can gather from comments made by members of the public, it is simply a matter of "accepting and bowing to the authority of university management" or, mutatis mutandis, of the government of the day. But is it that simple? Anyone familiar with the discipline that enables one to understand the often unconscious motives behind human behaviour, namely psychoanalysis, would know that it is not. Such motivations are often (including cases like the present protests) not easily or openly perceptible, and not straightforwardly subject to "rational argument", because they do not necessarily present themselves to conscious scrutiny. This is why one has to have recourse to psychoanalytic thinking, which enables one to come to grips with a phenomenon that would otherwise remain elusive.

Different theoretical perspectives in psychoanalysis overlap in productive ways for an understanding of protests or rebellion of any kind (on the part of individuals or groups). Here I shall concentrate, first, on two interrelated psychoanalytical concepts: "acting-out" and "transference". For Sigmund Freud (2011a: 2502), the difference between repetition and remembering is crucial in psychoanalysis - if the subject, due to (for example) resistance as a manifestation of repression, cannot remember certain traumatising events in the past, they "return" in the form of impetuous behaviour. Such behaviour is then the "acting-out" of repressed materials, and the psychoanalyst's task is to help the subject recollect them, lest she or he be caught in their repetitive grip interminably. Furthermore, as Laplanche and Pontalis (1973: location 287) remind one, for Freud "acting-out" is recognisable insofar as such behaviour appears to be impulsive, 
and as such not in keeping with the way such a person usually acts. However, the person who is "acting-out" usually does not grasp the significance of their actions.

In Seminar X of 1962-1963 (on Anxiety) Jacques Lacan (1962-63) augments the Freudian notion of acting-out in an important way - while agreeing with the basic Freudian concept, he points out that something crucial is missing in coming to grips with this phenomenon psychoanalytically, namely the "intersubjective" element, or what Lacan calls the domain of the (big) Other; that is, social normativity as embedded in the symbolic order of language. In other words, the remembering that was (correctly) at stake for Freud, is never a recollection in isolation, as the very practice of psychoanalysis underscores; it unavoidably has to be a recollection which is communicated verbally to another if it is to have a therapeutic effect. Lacan distinguishes between a "symptom" and "acting-out" as follows (1962-63: 84): " ... the symptom is not, like acting-out, calling for an interpretation. For - it is too often forgotten - what we discover in the symptom, in its essence, is not, I say, a call to the Other, is not that which shows to the Other, that the symptom in its nature is jouissance - do not forget it - a backhanded jouissance, no doubt, unterbliebende Befriedigung; the symptom does not need you as acting-out does, it is sufficient of itself ..."

A few pages further he (Lacan, 1962-63: 86; see also 82) reminds one that being "... addressed to the Other ... it [the acting-out] is therefore addressed to the analyst" (as representative of the Other, or society at large, insofar as it is embedded in the unconscious as the "discourse of the Other" - Lacan, 1977: 55). Hence, Lacan argues, "acting-out" occurs when the opportunity to communicate past events - specifically disturbing ones - to another is thwarted by the other (or the Other, that is, society at large), who cannot, or refuses to listen. And in the face of such deafness the subject resorts to "acting-out", even if he or she does not understand the import of their actions. Dylan Evans elaborates as follows (1996: 3): "When the Other has become 'deaf', the subject cannot convey a message to him in words, and is forced to express the message in actions. The acting-out is thus a ciphered message which the subject addresses to an Other, although the subject himself is neither conscious of the content of this message nor even aware that his actions express a message. It is the Other who is entrusted with deciphering the message; yet it is impossible for him to do so." [Hence the need for psychoanalysis.]

Interestingly, when one turns to the meaning of the often misunderstood concept of "transference" in psychoanalysis, it illuminates the meaning of "acting-out" further, because the two concepts are in a sense opposed, or perhaps rather stand in a tensional relation to each other. While "acting-out" on the part of the subject or analysand designates the (irrational) "return of the repressed", which has been blocked from 
conscious linguistic articulation by failing to remember (and which stands in the way of progress in analysis), "transference" denotes the process in which the relationship between the subject and the analyst unfolds. In other words, for Lacan it has the "structure of an intersubjective relationship" (see Evans, 1996: 213-216 for a succinct account of the development of Lacan's thought on transference). Lacan puts it this way (1991: 109): in "... symbolic transference ... something takes place which changes the nature of the two beings present".

Although both Freud and Lacan note the strong affects (like love, aggressivity and hate) which are brought into play in the transference, Lacan insists that the significance of the transference is essentially to be found in language, or "the love of knowledge" (Evans, 1996: 214). The most important aspect of "transference" that throws light on "acting-out" is this: while "transference" promotes intersubjective communication, understanding (albeit misunderstanding) and hence therapeutic effects, "acting-out" represents "resistance" to such therapy. It is therefore interesting to note that, for Lacan, "transference is the attribution of knowledge to the Other" (Evans, 1996: 214), with the supposition that "the Other knows". In its absence, a therapeutic development is unlikely to occur. This line of thinking is fleshed out in Lacan's Seminar 11 (2004), where he develops a conception of transference that is most relevant to the present theme of protestors "acting out" in the face of what might be described as a "subject supposed to know" (the Other), who has become "deaf". For the equivalent of transference to occur, there has to be some indication that "the subject who is supposed to know exists somewhere" (Lacan, 2004: 232). Lacan reminds his audience (or readers) here (2004: 231) that, in the Symposium, Plato already demonstrated rigorously what is at stake in the transference (something Lacan discussed at length in Seminar VIII, on Transference; 1960-1961), where "the subject supposed to know" is the character of Socrates. It is clear from Lacan's (2004) discussion of this supposition that no one could expect the psychoanalyst to have "absolute" knowledge - if anyone in this field could be said to know, it would have been Freud, when he was alive, and therefore the psychoanalyst as "subject supposed to know" constantly has to revert to Freud's legacy to fulfil this role, however inadequate.

While the theme of this paper does not involve analysands in an analytical relationship with psychoanalysts, it is arguably the case that, in light of the protesting students' behaviour lending itself to interpretation in terms of "acting-out", the analogy can be extended to the notion of "failed transference", given the lamentable absence of the "subject supposed to know", embodied by authorities that appeared to be trustworthy on the basis of demonstrable "knowledge". Evidently, judging by the remonstrations of the students concerned, such a subject in the know did not exist, as far as they were concerned, at least not in the guise of university authorities. In ordinary language this 
means simply that they saw no reason to trust the "authorities" in the guise of university management or government officials (see Summary of the Fees Must Fall student protest movement under References). To be sure, as a critic has reminded me, this does not necessarily mean that there was (or is) no authority recognised by these students. As Saleem Badat (2016: 14) points out, evidence suggests that "key student protest movement intellectuals and other protestors have been reading... Biko and Fanon". If this implies (as it apparently does) that they accepted the authority of these thinkers, I would submit that a chasm separates the latter and university as well as government authorities in this regard.

These considerations seem to cast the current student protests in a more comprehensible light, one that "authorities" at South African universities ought to take note of, since they seem to have been "deaf" to the "message" of the students up to this point - something that will receive more attention below. It also explains why Lacan was sympathetic to the student protests of the late 1960s (Evans, 1996: xxii): the "authorities" had not listened to their "message", but turned a deaf ear, and hence the protests can be seen as "actingout", in the same way as the local protests can be construed as such. Put differently, until the authorities can legitimately be seen as "people who know" by the students, and "transference" can take place, these protests will not be resolved. Repressed, unresolved issues have a way of being channelled through "any body" (or "any bodies") that can serve as a conduit for "acting-out" that which did not, or could not, be communicated intersubjectively.

It should be noted that among the unresolved issues at stake, one of the (if not the) most important concerns the economic factor of inequality and hence, economic disempowerment, just as it played a crucial role in the student protests of the 1960s in France and elsewhere. People often forget that the latter - not just in Europe but also in the US at the time - marked one of the greatest crises in capitalism's history, and it is no accident that then, as now, the students formed an alliance with economically disempowered workers. Hence, for "transference", and therefore "therapy" or recuperation to happen, these economic issues should be addressed, which cannot be done without addressing the "problem of capitalism" - the hard, traumatic kernel within the mass of student bodies "acting-out" their repressed distress - in today's increasingly unequal society (see References entries on student protests, particularly Lesane, Nkushubana \& Zulu, 2015).

\section{Freud on group psychology}

The preceding interpretation of the current student protests would be incomplete if one did not augment it by means of Freud's Group psychology and the analysis of the ego of 1921 (Freud, 2011). I say this because of the prominence of group behaviour, 
particularly of a destructive nature, in recent months - not only in the student protests referred to earlier, but also the pre-local elections protests such as those in the Tshwane area recently (in 2016). The question it prompts is the same one that Freud set out to answer almost a century ago, namely: why do groups sometimes behave in such strikingly different ways compared to individuals? Freud was not the only author reflecting on this issue at the time just after the First World War, which had demonstrated the importance of understanding group behaviour - it is no accident that one of the two highly organised groups that Freud discusses here is the army. In his text he takes due cognisance of all the important thinkers who had written on it before him and, good researcher that he was, first weighs up their contributions carefully before either showing why it should be discounted or what he wishes to retain from it before forging ahead with his own investigation. In the course of considering the contributions of a number of thinkers, Freud distinguishes between "unorganised" (or random) and "organised" groups, and adds what he regards as a crucial element ignored by other writers, namely "libidinal ties" among the members of groups, ties through "identification" with "leaders" (a significant concept in this context, in contrast with "masters", as will be shown later) and with one another, as well as focusing on the relevance of suggestibility and hypnosis.

The author whose work on the "group mind" Freud (2011) refers to most approvingly (before extending it with his own ideas), Le Bon, characterises it, first, by insisting that a group's collective behaviour is completely distinct from that of the individuals comprising it - generally, individuals in groups lose "higher" modes of functioning in favour of more regressive behaviour. According to Le Bon, in contrast with individual behaviour, groups are "impulsive, changeable and irritable", "led .... by the unconscious", un-premeditated, feel omnipotent, are credulous, uncritical, do not doubt themselves, incline to extremes, want to be "ruled" by strong masters, lack the inhibitions of individuals, show signs of regression to mental primitivity (like tolerating contradictions, as in the case of the unconscious, as Freud reminds one, are susceptible to the "magical power of words" instead of reason, and (like neurotics) desire illusions instead of truth. As Freud (2011: 3775) approvingly comments on Le Bon's findings: “.... in the mental operations of a group the function of testing the reality of things falls into the background in comparison with the strength of wishful impulses with their affective cathexis".

Freud's (2011) criticism of Le Bon begins with his insistence that Le Bon overlooks the fact that there must be "something" that unites the individuals in the group in the first place. His own answer to this question is twofold: Le Bon overlooks the important unifying role of "leaders", and most importantly - after examining the structure of two highly organised groups (church and army) - Freud corrects and amplifies all the theories he has considered by positing libido (love or Eros in the encompassing sense) 
as the most significant unifying force in the psychic functioning of groups (which must be presupposed to explain phenomena such as suggestibility and "contagion" in groups). To the degree that a group (of which there are many kinds, varying in durability and organisation) displays a cohesion of some kind, libidinal ties are present, but importantly, if something should occur to weaken those libidinal or emotional ties, the (organised or historically cohesive) group's functioning would be fundamentally disrupted - for instance in the form of panic (in the case of an army), or - significantly for the present investigation - in the eruption of "acts of violence".

Importantly, though, Freud (2011: 3814) also says the following about "random" groups, which resonates with Le Bon's characterisation:

"The psychology of such a group, as we know it from the descriptions to which we have so often referred - the dwindling of the conscious individual personality, the focusing of thoughts and feelings into a common direction, the predominance of the affective side of the mind and of unconscious psychical life, the tendency to the immediate carrying out of intentions as they emerge - all this corresponds to a state of regression to a primitive mental activity, of just such a sort as we should be inclined to ascribe to the primal horde. Thus the group appears to us as a revival of the primal horde. Just as primitive man survives potentially in every individual, so the primal horde may arise once more out of any random collection; in so far [sic] men are habitually under the sway of group formation we recognize in it the survival of the primal horde. We must conclude that the psychology of groups is the oldest human psychology ..."

It will be recalled that "acting-out" is a phrase denoting action that is irrational, and is rooted in repressed feelings like frustration, anger and/or anxiety. When this is placed in the context of the group psychology mapped out by Freud, new insights arise, for instance that "acting-out" may easily occur in unorganised groups (including organised groups that have lost their libidinal ties with a "leader").

In light of the above I want to propose that the student protests in South Africa - and, although this is not the primary focus here, pre-election events in Tshwane, too - can be understood by considering the different aspects of group-psychology operative there. Firstly, South Africa is a country where a dominant, organised political party (the African National Congress), bound together by more than a century of historically cemented libidinal and leadership ties, comprises the backdrop to current protests of any kind, insofar as such protests are implicitly aimed at this party (in light of expectations raised by its governing role for more than 20 years since 1994). This is the case, even if they also target "whiteness" insofar as universities are perceived as predominantly "white" institutions that have failed, since 1994, to change their

PINS [Psychology in Society] $53 \cdot 2017 \mid 36$ 
institutional culture at a fundamentally structural level, opting instead for a process of "assimilation" (Badat, 2016: 11). Secondly, the protests concerned - both student and pre-election protests - appear to have been largely driven by unorganised groups that have on occasion gone on the rampage like a "primal horde", where reason disappeared and made way for immediate gratification of desires. For example, regarding pre-election protests, reports indicate that, in response to the ANC's announcement of Thoko Didiza as mayoral candidate for Tshwane in imminent local government elections, groups of dissatisfied residents took to the streets to express their outrage, setting vehicles alight, blocking roads and looting businesses (Sunday Times Staff Reporter 2016). There were even reports that people had been killed in protest-related violence (Bateman et al, 2016). In response to the violence, the ANC warned that party members involved in the violence would not be "protected" (Kekana \& Lindeque, 2016).

In the light of Freud's analysis of group psychology this may be understood as follows. The ANC is a highly organised group, for decades sustained by the kind of libidinal ties Freud describes. For various reasons (too many to be discussed here), these libidinal ties have been weakening for some time, with regular reports (and complaints) of factionalism in the organisation (Letsoalo \& Hunter 2015; Makhafola 2015). Under these circumstances actions that are perceived by ordinary members as signs that the organisation's leaders are acting contrary to members' interests would understandably "weaken" or destroy the emotional/libidinal ties holding them together; hence the ensuing violence. It may be argued, validly, that weakened libidinal ties are, although necessary, not a sufficient condition for violence. But when Freud's contention, that unorganised groups sometimes regress to the psychological level of the "primal horde" - which possesses neither rhyme nor reason - is recalled, it does not appear far-fetched to claim that the weakening of libidinal ties, as described above, gave rise to violence.

I am well aware that there is another factor to consider in relation to student protests as well as those surrounding local elections - which may be shown as being fundamental to the ones discussed so far - namely the undergirding economic reality of the unequal distribution of capital, as evinced in the students' claim that insufficient funding is available for (higher) education, and the fierce competition between various individuals for positions on the nomination-lists for local elections. In other words, the fact that there is money involved here is of decisive importance. But the very fact that money can make a difference to the acceptance of the status quo in these two areas of socioeconomic and political activity testifies to the waning of libidinal ties that customarily held the party together, and which have been eroded by the virus of money, among other things (Allison 2015; Azikiwe 2016; Hall 2016; Lancaster 2016). The following section of this paper will focus on the significance of capital for the protests in question. 


\section{Lacan and the discourse of the capitalist}

The question of money is by no means incidental here. On the contrary, it is crucial for understanding these protests in the present historical context, that of the hegemony of capital. It is Lacan's (2007) work on the "four discourses" that enables one to perceive the significance of Freud's reflections on group psychology - specifically what he says there about the "leader", as opposed to the "father" - in the context of capitalism. Recall that Freud talks about the identification of the subject in an organised group with the "leader" (whether this is the leader of the church or of the army), in whom the ties of love binding the group together are anchored. In fact, the leader may be regarded as the metonymy of the group, insofar as its cohesion depends on him or her - should the leader be destroyed or removed, such cohesion would be undermined. But although the question of identification with a leader may seem to be irrelevant, because the protests under discussion here were (as suggested by the evidence) "leaderless", in the light of Lacan's reflections this is not the case, as I shall argue below.

As hinted at above with regard to money, therefore, when society is saturated with capitalist imperatives, as in post-1994 South Africa, where political leaders have enriched themselves shamelessly in full view of the poor, and the country has dropped below Brazil to the dubious level of being "the most unequal society in the world" (Klein, 2007: 198), one has to amplify the interpretation of these protests. Are these leaders in the Freudian sense? And what would it mean for the cohesion of the group if they were to be perceived as enriching themselves? To be able to answer these questions one has to return to a specific thread in Lacan's seminar on The other side of psychoanalysis (2007) - that of capitalist jouissance. As it turns out, in the (1969-1970) seminar conducted in the context of the 1968 student uprisings in France and around the world, Lacan was understandably interested in Freud's essay on Group psychology - a very modern discourse about group cohesion - as opposed to his Totem and taboo (Freud, 2011b) for example, where the parricidal brothers have no sooner murdered the tyrannical, privative father to be able to get their hands on the mother and sisters, than their collective guilt impels them to forswear incest and project the image of the dead father into that of an omnipotent God: in one mythical instant society and monotheistic religion are born. By contrast, as set out earlier, Group psychology proposes that ties of love, emanating from, and reciprocally to, the leader are the ground of (organised) group cohesion.

Groups imply the social bond. For Lacan (2007) a discourse is what structures the social field by linking signifiers in different ways. This relation between signifiers means that a specific signifier represents the subject for another signifier in a manner that determines how the social field will be structured in terms of power relations. Lacan provides a typology of discourses by indicating four different sets of relations among four signifiers, where each different arrangement among them produces a different discourse, and 
therefore different power relations. The signifiers and what they denote are: $\mathrm{S} 1$ - master signifier; S2 - knowledge (knowing that ...); \$ - the divided subject; a - objet a or surplus pleasure; and the four different permutations involving them produce four different discourses: those of the master, the university, the hysteric, and the analyst, respectively. In the case of the master's discourse the master signifier (S1) is in the position of the Agent that commands the Other (\$2), while repressing Truth (of the divided subject, \$) and producing surplus pleasure (a). In ordinary language this means that a master's discourse organises the social field by commandeering knowledge, generating pleasure and concomitantly repressing an awareness of fallibility on the part of subjects who are agents of the master's discourse. When, in the case of the university discourse, the signifier for knowledge (S2) moves into the position of Agent, commandeering or organising the social field through the surplus pleasure of objects (a), this is achieved by repressing the awareness that the master signifier (S1) lurks behind it, and generates the subject (\$) split between conscious knowledge acquisition and unconsciousness regarding the possibility of such knowledge.

What is most relevant for the present paper is Lacan's contention, that the signifier for knowledge (S2), in the position of Agent in the university discourse, may be understood as representing capitalist knowledge. Put differently, the university discourse in the present era has become the discourse of the capitalist. In other words, capitalist discourse today consists in the utilisation of knowledge by commandeering the (surplus) enjoyment of objects (a) socially and economically, concomitantly generating subjects divided between conscious awareness and unconsciousness regarding their formation as subjects (of capital). Interestingly, Lacan shrewdly indicates that (2007), historically, this shift occurred around the time of Luther and Calvin (that is, around the $16^{\text {th }}-17^{\text {th }}$ centuries), with the rise of capitalism; hence the need for accounting, which presupposes calculability. (In a different context, that of the rise of modern physics, Heidegger [1977] confirms this as being the epochal time of calculability as the decisive mark regarding relations between natural objects.) In brief, according to Lacan the historical shift of the signifier (S2) for knowledge (the university, or capital), into the position of Agent - and concomitantly of the signifier (a) for surplus enjoyment (jouissance) into the position of Other, commanded by the signifier for knowledge - marks the inauguration of an era in which knowledge production (as capitalist production) would become the hegemonic discursive power in the world. It is no accident that Lacan (2007: 81) remarks of economics - "this other field of energetics" - that it "is the field of jouissance". During this time one would witness the replacement of the master and the father, as figures of authority, by that of the "leader" in the Freudian sense, who no longer "lords" it over his (or her) subjects or people (as Louis XIV, the modern "master par excellence" [Žižek, 2006: 109], did) but is everywhere conjoined with them, so that one might say - as already intimated - that the leader radiates the cohesion, or is the metonymy of, the people in 
the group. And Lacan enables one to understand that the place of jouissance today, at a time when the economic sphere is the undeniable locus of power (Bakan, 2004; Klein, $2007,2014)$, is crucial for grasping the cratological (power-related) place of, as well as resistance to, "democratically elected" leaders. What are the connections here?

First one should note that, as Žižek (2006: 108) points out, the hegemonic discourse of modernity, namely that of the university, appears in two countervailing forms "self-revolutionising" capitalism, and bureaucratic "totalitarianism", which has been conceptualised in various guises, including Foucault's "biopolitics" - neither of which can be reduced to the other. It is instructive to note that biopolitics - the quasi-pastoral control over the life of its citizens in its entirety by the state - corresponds with what Adorno described as "instrumental reason" or "the administered world" (Žižek, 2006: 108-109), in other words, the bureaucratic society. That this is perfectly congruent with a world in which the university discourse is hegemonic, is confirmed by Žižek (2006) where he reminds one that Lacan, far from associating university discourse directly with the university as institution, saw in the Soviet Union the embodiment of its rule. In other words, bureaucracy, or the "planned transparency of social life" (Žižek, 2006: 109), epitomises the university discourse - not surprisingly, because bureaucracy has the answers to all the questions one might ask, and therefore represents the paradigm of systematically unified knowledge (which is not the true discourse of science, of course; it is the hysteric's discourse that exemplifies this through its constant questioning [Olivier, 2009]). The relevance of these considerations lies in the fact that the university discourse manifests itself, today, in "biopolitical" administrative machinations, on the one hand, and - as noted above - in capitalist "logic of the integrated excess" (Žižek, 2006: 108), on the other. I mention this because one should not make the mistake of maintaining a strict distinction between the discourses of the university and that of the capitalist in the current era - as Žižek (2006) confirms, Lacan argues explicitly that today, the two are conflated. It further means that politicians and university leaders are mere functionaries of the bureaucratic administrative system serving capital, and not "masters" in whom authority is vested - small wonder that they did not "listen" to the protestors - they were structurally deaf!

In the light of the above the protestors' actions can be understood as being directed at a discursive system which empowers its functionaries, but from which they were/are excluded. Insofar as their actions might be construed as questioning the hegemonic system - the university discourse - the students occupy the position of the hysteric in discursive terms, where the divided subject (\$), the truth of whom is surplus enjoyment of the lost object (a), addresses the master signifier ( $\mathrm{S} 1$ ) as Other, producing knowledge (S2), except that here it is the signifier for knowledge that is indirectly addressed or questioned insofar as the master-signifier today has been replaced by the capitalist in 
the position of the signifier for knowledge. The following three excerpts from student protestors' remarks arguably confirm my interpretation.

"If I have to drop out of school because I couldn't not [sic] afford the fees, it will be big disappointment to everyone. It's unfair to have to struggle just to get an education in this country and yet we are told it's the most developed country in Africa. I'm sitting with student debt of close to 100,000 rand $(\$ 7,328 ; £ 4,774)$ to repay as soon as I start working. I'm from a family where my father is the sole bread winner, he works as a cleaner at a lodge - he makes very little money" (Thembile Lesane, BBC, 2015).

"My mother is paying for my fees and the rest covered by NSFAS. It's a real struggle for her. Making tertiary education so difficult to acquire is a big problem - especially when it's being done by the [governing] African National Congress (ANC) which has been promising us free education since 1994. Tertiary education is now a privilege or for the rich in this country and it shouldn't be like that, anyone who is academically deserving should be able to further their studies if they want to. I cannot afford university fees and if they were to go up then I won't be able to do a post-graduate degree and many places don't hire you unless you have a post-graduate degree - we have many unemployed people sitting at home with undergraduate degrees - the entire system is flawed... They are now doing to us what the apartheid government did to them - except this is academic exclusion, it is financial exclusion" (Ntokazi Nkushubana, BBC, 2015).

"Education has become about how rich you are and that's some type of discrimination - that doesn't sit well with me. All of this boils down to finance and corruption, we need this addressed. I think the government is too comfortable at the moment and they need to be shaken up a bit. For me this goes beyond a protest about fees, there are bigger issues that need to be addressed such as inequality" (Taonga Zulu, BBC, 2015).

All of these statements unambiguously indict the dominant discourse, namely that of the university, or capitalism (which are here the same), represented by "tertiary education" and "money/finance/fees". However, insofar as they do so in the mode of questioning, which constitutes the discursive position of the divided subject ( $\$$ in the discourse of the hysteric), their questioning is (implicitly or explicitly) directed at the master-signifier (S1), here represented by the governing party, the ANC. It is important to note that (as indicated above) the "product" here is the signifier for knowledge (S2), while the (hidden) truth (a) is the surplus pleasure of the (lost) object, which is the repressed driving force or cause of the split subject's (\$) desire. What this means in everyday language is that the challenging or questioning of government (or, for that matter, university authorities, structurally in the same position as government representatives) has the effect of 
generating knowledge (which is occurring in the writing of this paper, for example), and that the "truth" about what it is that drives their questioning will forever be hidden from the knowledge that is generated - if it were known with certainty, people would not be writing papers or books about it. It is in this sense that Verhaeghe (1995: 11) can say that the history of science is a: “... hystory: science has always been an attempt to answer the existential questions, and the only result of that attempt is science itself ... This is all the more clear in human sciences where, for example, even psychoanalysis is a product of hysteria, but the same thing can be said of every development of knowledge, even on a strictly individual level. A developing subject wants to know the answers about his own dividedness: that's why he keeps on reading, speaking etc. He will end up with a considerable body of knowledge, but that doesn't teach him very much about his own lost object at the place of truth."

\section{The university discourse, capitalism, jouissance and protests}

Juliet Flower MacCannell (2006) adds another perspective in her compelling reading of the "discourse of capitalism" in Seminar 17. By organising the social field around knowledge, which produces surplus enjoyment or jouissance, the master's discourse (for example the monarchical discursive power of Frederick the Great of Prussia) acknowledges the lack which it is aiming to overcome at two levels, by producing knowledge and profit "for the whole" (the people), instead of only a part of it (like the private sphere) through the work of the slave (MacCannell, 2006:). This changes when the signifier for knowledge (S2) assumes the position of agency in the university discourse. Where knowledge (the slave, or historically, universities) was commanded as agent by the master signifier (S1) in the master's discourse, now it is the signifier for knowledge which organises or sets to work surplus enjoyment or jouissance (a). It is precisely the role of the latter which alters decisively when the master's discourse is replaced, historically, by the university discourse (MacCannell, 2006; Lacan, 2007). In Lacan's words, which hint at the connection between surplus value (in Marxian terms) and surplus enjoyment (2007: 178): "Surplus value combines with capital - not a problem, they are homogeneous, we are in the field of values". "Moreover," he adds with heavy irony, "we are all up to our necks in it, in these blessed times in which we live". But what does this mean in terms of changed power relations? MacCannell articulates this strikingly (2006: 201):

“... a fantastic immersion in a substance that is nothing other than accumulated jouissance - unspent, and at a safe remove from the whole apparatus that actually produced surplus enjoyment: the signifier, metaphor ... A social revolution has taken place. The worth of an individual is no longer defined by his condition, but by his market value, free as he now is to sell his labor. He does not realize, however, that he is also selling out his know-how (savoir-faire), which has inhered in his work all 
along ... The secret of the worker himself is to be reduced to no longer being anything but a value."

What does this mean? Keep in mind that "discourse", for Lacan (2007: 13), is a function of relations between signifiers, as is evident from his claim that "discourse [is] thought of as the status of the statement" (where "status" appears to denote the different ways in which signifiers comprising the statement can articulate relations as stable, unstable, and so on, that is, in terms of power, for example the statement: "The oil companies are lobbying politicians for their support"). Neither can the subject be divorced from discourse. In fact, for Lacan (2007: 13) the subject emerges where "the signifier functions as representing this subject with respect to another signifier", implying that the subject is ineluctably the function of a relation between signifiers, that is, a function of language as discourse. Without language, or rather, discourse, which "goes much further than actual utterances" (ibid), as it implicates non-verbal structures, no subject. Moreover, the role of jouissance - perhaps one of the most puzzling concepts in Lacan's work - is crucial here.

The latter is exemplified in the "fort/da" game played by Freud's grandson (Freud, 2011c), insofar as it represents a repetition of something that is paradigmatically masochistic - fusing pain and pleasure - given its relation to what Freud regarded as the game's painful reminder of the mother's absence (Freud, 2011c), making the latter an exemplary instance of the "lost object", and the cotton reel the object a that signifies its functioning. Here is the crux of jouissance: far from being simply pleasure or enjoyment, it is surplus pleasure insofar as it is the "beyond" of enjoyment - Romeo and Juliet's "parting", which is "such sweet sorrow" - where pain and pleasure merge. It is what Antigone experienced in embracing death for the sake of her dead brothers (Lacan, 1992), and - less dramatic, but equally apt - what the exemplary capitalist worker subject gains when he or she obsessively repeats the masochistic ritual of capitalist work every day (Parker, 2011), confirming their status as merely a "value" in the bigger, "surplus value", scheme of things.

What is the importance of jouissance in the present context of understanding the role of money (as major signifier of capitalism) in protests where libidinal bonds binding members of a group were not sufficient to prevent these uprisings, then? Recall that, in the present age, one witnesses the hegemony of the university (formally the same as the capitalist) discourse, where the signifier for knowledge or surplus value (S2) commands the cause of desire, surplus enjoyment or jouissance (a), which means the latter is in the service of the former. As MacCannell reminds one (2006: 202), the knowledge at issue here is "cumulative knowledge, a wealth of know-how...tied directly to surplus enjoyment". She proceeds to observe that: "The producer of knowledge is now repaid 
not with ignorant jouissance (like the slave [in the master's discourse]) but with identity: he now identifies himself with wealth ..." (ibid) What she is saying is that wealth (or surplus value) is synonymous with knowledge in the present era, that it is intimately tied to surplus enjoyment or jouissance, and that in this schema a sense of identity is inseparable from wealth. Furthermore, MacCannell (2006: 202) notes that "Surplus enjoyment then is entirely analogous to capital - or in current terms, 'wealth-creation'”.

These insights pave the way for understanding an uprising that cannot be separated from "wealth-creation", nor from the identification with it among disaffected students or aspiring party-candidates. As pointed out earlier with reference to student protestors' statements and reports of violence prior to local elections, the persistent economic inequality in South Africa played a prominent role in both the student protests during the "fees must fall" campaign and the violence preceding recent local elections. Not only is wealth-creation germane to these events, but also the question of (political) leadership in South Africa, because, as Lacan intimates (following Freud), in these capitalist times (MacCannell, 2006; Lacan, 2007), it is no longer the primordial father or the master whose signifier is in the discursive position of agent, but that of the leader, which coincides with the signifier for surplus (economic) value or knowledge (S2). Keeping in mind that political leaders, today, when the agent signifier indexes economic surplus value or knowledge, are leaders in the field of the economic, it is interesting to note that Lacan (2007) locates the psychical source of the capitalist's discourse in the child's identification with the father as impotent. That is, at a time when the child is sexually immature, accumulating "libido capital" as surplus jouissance, it wistfully "replaces" the disempowered father with itself. Small wonder that, as MacCannell (2006: 204-205) perspicaciously notes, leaders under capitalist conditions are infantile: such "childlike leaders ... dispense with the masterly/paternal engines of value and meaning-creation ... in favour of what is already accumulated as surplus enjoyment - already capital ... Wealth is the discursive quilting point (point de capiton) the leader automatically embodies".

The protestors in question are therefore in the position of the infant who wishfully identifies with an impotent father, that is, a father who is not really a father - the model for the (capitalist) leader. And like the infant they accumulate surplus jouissance in advance, triggered by their desire for the elusive object of wealth that, as objet $a$, takes the place of the "lost object". A close reading of the statements by the three student protestors, quoted earlier, reveals as much: whether it is the claim that tertiary education in South Africa today is for the rich, or that it is ultimately a question of equality, it seems apparent that they identify with that which the "leaders" embody, namely material wealth. Simply put, their protest is motivated by their exclusion from this perceived wealth (registered in one student's observation, that South Africa is held up as Africa's "most developed" 
country), which collides unbearably with their wealth-identification. On the one hand they have been placed in a situation where the university (today synonymous with capitalist) discourse establishes the prevailing social bond, but simultaneously they are denied a place in this specific economic set of social relations.

\section{Protests, leaders, capital and exclusion from surplus enjoyment}

Taking into account all of what the theoretical lenses have brought into focus, above, what has one learned regarding the actions of the protestors concerned - disaffected students and pre-election voters or would-be party candidates? One already knows the Freudian grounds on which these protest actions can be interpreted in terms of the tension field between "acting-out" and "transference", as well as grasping them against the backdrop of group-psychology as articulated by Freud. It will be recalled that, at one level, Freud's group psychology enables one to perceive the protests as (at least partly) the effect of the loosening, or perhaps disintegration of the libidinal bonds that formerly held the party (the ANC) together. Amplifying the scope of the Freudian lens with that of Lacan has also highlighted different aspects of these phenomena, and - in the case of Lacan's claim that the hegemonic discourse of the present era is that of the university, which has increasingly become synonymous with that of the capitalist - has added a crucial focal area: that of the pertinence of the link between surplus economic value and surplus enjoyment or jouissance. It has been my argument that the behaviour of the protestors in question can be comprehended as a function of their exclusion from the field of "knowledge" (embodied by the university) which is inseparable from surplus enjoyment or jouissance, in its turn tied to the wealth with which they identify through those perceived as "leaders".

Summing up the insights gained through the argument, above, one might say, succinctly, that at an unconscious level the protest behaviour was motivated by the identification, on the part of the protestors, with leaders who embody capital as wealth. In fact, the protestors identify themselves, as seen above, with wealth as such - wealth from which they have been cut off by lack of funding (in the case of the student protestors), or by the dismaying prospect of being omitted from party-lists (in the case of pre-election protestors who probably relished the lucrative prospects of being installed as municipal councillors). Keeping in mind the conspicuous financial benefits of party leaders in South Africa - who, as "leaders" differ fundamentally from those who embodied the "father" or the "master" in previous eras, where the latter commanded knowledge for the benefit of the whole - to be cut off from the (knowledge-) sphere of surplus economic value means, ipso facto, to be cut off from surplus enjoyment, which is unbearable. Hence the "acting out", which, one should recall, happens in a situation where leaders are perceived as hogging the surplus in question, and where the Other (embodied in politicians and university leaders, 
among others) has become "deaf", and understandably so, because the protestors constitute a threat to the maintenance of exclusive access to the wealth in question. This would explain (in a different register to the usual one) the protestations on the part of government ministers, in the face of the protestors' demands, that there are insufficient financial resources available for the funding of free higher education.

Some readers may find these findings inconsequential - particularly those arrived at via Lacan's theory of discourse. Against such a perception I would argue that one ignores this part of Lacan's work at one's peril. His perspicacity regarding the historical shift from the dominance of the master's discourse to that of the university in an era of the so-called "knowledge economy" has far-reaching implications, especially because the very phrase, "knowledge economy" confirms the accuracy of his claim, that the signifier for knowledge (S2) today represents specifically capitalist knowledge, with the consequence that the university discourse has really become the capitalist discourse. Although it is true that Lacan later provided a different formulation of the capitalist's discourse (Olivier, 2009), it does not invalidate his remarks about the historical ascendancy of capitalism in Seminar 17, as discussed in this article. The position of the master signifier (S1) in the place of "truth" in the university discourse means that it is the hidden driving force behind the way that the signifier for knowledge, or the knowledge-economy (S2) directs itself at the signifier for surplus pleasure (a). This alone indicates that (capitalist) knowledge is today the organising power in establishing social links, in the process generating divided subjects ( $\$$, in the place of product), who are systematically unable to grasp the significance of the master signifier (S1) underpinning that of the knowledge-economy (S2) (Verhaeghe, 1995). It is therefore no surprise that people do not generally grasp the fact that neoliberal capitalism has replaced democratic politics as the locus of power, and that attempts to comprehend powerrelations, psychologically and otherwise, have to take this into account. Moreover, in light of the fact that the theory of the four discourses provides a matrix of interpretation of the power-relations embedded in social links manifesting themselves discursively at all times, the shifting power-relations in the early $20^{\text {th }}$ century - not only in South Africa but globally; think of Donald Trump's rise to power in America - constitute fertile ground for interpretations of this kind.

\section{References}

Allison, S (2015) South African students score tuition fee protest victory. https://www. theguardian.com/world/2015/oct/23/south-african-students-protest-pretoria-tuitionfees-rise (Accessed 7 July 2016). 
Azikiwe, A (2016) Pre-election violence in South Africa. http://www.globalresearch.ca/ pre-election-violence-in-south-africa/5533154 (Accessed 7 July 2016).

Badat, S (2016) Deciphering the meanings, and explaining the South African higher education student protests of 2015-16. WISER, Wits University, Johannesburg.

http://wiser.wits.ac.za/system/files/documents/Saleem\%20Badat $\% 20-\% 20$ Deciphering\%20the\%20Meanings,\%20and\%20Explaining\%20the\%20South\%20 African $\% 20$ Higher\%20Education $\% 20$ Student $\% 20$ Protests.pdf

Bakan, J (2004) The corporation. The pathological pursuit of profit and power. London: Constable.

Bateman, B, Kubeka, T, Mogale, K \& Manyathela, C (2016) Police confirm two deaths after Tshwane protests. http://ewn.co.za/2016/06/22/Police-confirm-2-deaths-afterTshwane-protests (Accessed 7 July 2016).

Chabalala, J (2016) Government appeals for calm at universities. http://www.news24. com/SouthAfrica/News/government-appeals-for-calm-at-universities-20160907 (Accessed 7 September 2016).

Evans, D (1996) Introductory dictionary of Lacanian psychoanalysis. London: Routledge.

Freud, S (2011) Group psychology and the analysis of the ego, in Smith, I Freud Complete works. e-book (pp 3763-3834) (1921-German).

Freud, S (2011a) Remembering, repeating and working-through, in Smith, I Freud Complete works. e-book (pp 2496-2506) (1914-German).

Freud, S (2011b) Totem and taboo: Resemblances between the psychic lives of savages and neurotics, in Smith, I Freud - Complete works. e-book (pp 2646-2799) (1913-German).

Freud, S (2011c) Beyond the pleasure principle, in Smith, I Freud - Complete works. e-book (pp 3713-3762) (1920-German).

Hall, M (2016) South Africa's student protests have lessons for all universities. https:// www.theguardian.com/higher-education-network/2016/mar/03/south-africas-studentprotests-have-lessons-for-all-universities (Accessed 7 July 2016). 
Heidegger, M (1977) The age of the world picture, in The question concerning technology and other essays. (trans Lovitt, W). New York: Garland Publishing (pp 115154) (German-various dates).

Kekana, K \& Lindeque, M (2016) ANC warns those involved in Tshwane protests won't be protected. http://ewn.co.za/2016/06/27/ANC-vows-not-to-protect-those-involved-inTshwane-protests (Accessed 7 July 2016).

Klein, N (2007) The shock doctrine. The rise of disaster capitalism. New York: Metropolitan Books.

Klein, N (2014) This changes everything. Capitalism vs the climate. Toronto: Alfred A Knopf.

Lacan, J (1962-1963) The seminar of Jacques Lacan, Book X: Anxiety. (Trans Gallagher, C). E-book for private use (2004-French).

Lacan, $J$ (1977) The function and field of speech and language in psychoanalysis, in Écrits: A selection. (trans Sheridan, A). New York: W W Norton (pp 30-113) (1966-French).

Lacan, J (1991) The seminar of Jacques Lacan, Book I: Freud's papers on technique 1953-1954. (trans Forrester, J). New York: W W Norton \& Company (1975- French).

Lacan, J (1992) The seminar of Jacques Lacan, Book VII: The ethics of psychoanalysis 1959-1960. (trans Porter, D). London: Routledge (1986-French).

Lacan, J (2004) The seminar of Jacques Lacan, Book 11. The four fundamental concepts of psychoanalysis. (trans Sheridan, A). London: Karnac Books (1973-French).

Lacan, J (2007) The other side of psychoanalysis. The seminar of Jacques Lacan, Book 17. New York: W W Norton. (1991-French).

Lancaster, L (2016) Desperate and divided, SA is gatvol. http://mg.co.za/article/2016-0211-will-south-africans-take-their-frustration-to-the-polls (Accessed 7 July 2016).

Laplanche, J \& Pontalis, J-B (1973) The language of psychoanalysis. (trans NicholsonSmith, D). London: Karnac Books (Kindle edition) (1967-French).

Lesane, T, Nkushubana, N \& Zulu, T (2015) South Africa \#FeesMustFall: Stories behind 
the protests, BBC Africa News, 23 October 2015: http://www.bbc.com/news/worldafrica-34592527

Letsoalo, M \& Hunter, Q (2015) Zuma blames factionalism for ANC membership decline. http://mg.co.za/article/2015-10-09-zuma-blames-anc-kingmakers-for-membershipdecline (Accessed 7 July 2016).

MacCannell, J F (2006) More thoughts for the times on war and death: The discourse of capitalism in Seminar XVII, in Clemens, J \& Grigg, R (eds) Jacques Lacan and the other side of psychoanalysis. Durham: Duke University Press ( $p p$ 195-215).

Makhafola, G (2015) Factionalism is a cancer: Mantashe. http://www.iol.co.za/news/ politics/factionalism-is-a-cancer-mantashe-1927829 (Accessed 7 July 2016).

Msimang, T (2016) Classes resume at University of KwaZulu-Natal. SABC News: http:// www.sabc.co.za/news/a/7e66a0804e0ba52686aab749e1a112b8/Classesundefinedres umeundefinedatundefinedUniversityundefinedofundefinedKwaZulu-Natal-20162908 (Accessed 29 August 2016).

Olivier, B (2009) Lacan and the discourse of capitalism: Critical prospects. Phronimon: Journal of the South African Society for Greek Philosophy and the Humanities, 10(1), 25-42. [Reprinted in Olivier, B (2012) Intersecting philosophical planes:

Philosophical essays. London \& Frankfurt: Peter Lang Academic Publishers (pp 47-67).

Parker, I (2011) Lacanian psychoanalysis: Revolutions in subjectivity. London: Routledge.

Student protests:

See http://mg.co.za/tag/student-protests, particularly http://mg.co.za/article/201603-23-student-protests-dont-waste-this-crisis; http://mg.co.za/article/2016-03-03-therainbow-is-dead-beware-the-fire-sa; http://mg.co.za/article/2016-01-20-fees-are-justthe-start-of-change; http://mg.co.za/article/2016-02-18-student-protests-forge-linkswith-past (Accessed 7 August 2016).

Summary: Fees must fall: https://en.wikipedia.org/wiki/FeesMustFall (Accessed 7 August 2016).

Sunday Times Staff Reporter (2016) In pictures: Tshwane in chaos: http://www. timeslive.co.za/sundaytimes/stnews/2016/06/21/In-Pictures-Tshwane-in-chaos (Accessed 7 July 2016). 
Verhaeghe, P (1995) From impossibility to inability: Lacan's theory on the four discourses. Originally published in The letter. Lacanian perspectives on

psychoanalysis, 3, Spring (pp 91-108). Available online at: http://www.psychoanalysis. ugent.be/pages/nl/artikels/artikels\%20Paul\%20Verhaeghe/From\%20Impossibility $\% 20$ to\%20Inability.pdf (pp 1-14) (Accessed 5 January 2017).

Whittles, G (2016) Tensions high after UFS rugby game brawl. Eyewitness News: $\underline{\text { http:// }}$ ewn.co.za/2016/02/23/UFS-suspends-classes-after-black-vs-white-brawl) (Accessed 7 August 2016).

Žižek, S (2006) Object $a$ in social links, in Clemens, J and Grigg, R (eds) Jacques Lacan and the other side of psychoanalysis. Durham: Duke University Press (pp 107-128). 